\title{
Assessment of Tight-0il and Tight-Gas Resources in the Junggar and Santanghu Basins of Northwestern China, 2018
}

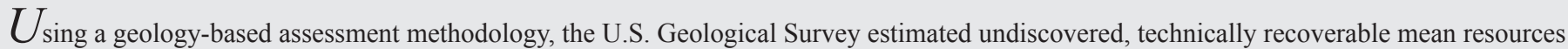
of 241 million barrels of tight oil and 10.1 trillion cubic feet of tight gas in the Junggar and Santanghu Basins of northwestern China.

\section{Introduction}

In 2018, the U.S. Geological Survey (USGS) quantitatively assessed the unconventional (continuous) oil and gas resources in two previously unassessed formations in northwestern China. These include an assessment of tight-oil resources in the lower Permian Lucaogou Formation (Yang and others, 2010) of the Santanghu Basin (Altay-Sayan Folded Region Province) and tight gas in the Lower Jurassic Badaowan Formation (Guo and others, 2014; Yang and others, 2015) in the southern part of the Junggar Basin (Junggar Basin Province) (fig. 1).

Lacustrine mudstones of the Lucaogou Formation are present in several basins and intervening uplifts in northwestern China (Carroll and Wartes, 2003). Tight oil is produced from this formation in the Junggar Basin, and in 2016, the USGS completed an assessment of tight-oil and tight-gas resources in the Lucaogou of the Junggar Basin (Potter and others, 2017). Over the past 15 years in the Santanghu Basin, oil has been discovered and produced from several types of tight reservoirs in the Lucaogou Formation; this oil has apparently undergone short-distance vertical migration from interbedded organic-rich mudstone (Hackley and others, 2016).

The thick Lower Jurassic Badaowan Formation in the southern Junggar Basin represents a fluvial and shallow lacustrine system containing low-permeability channel sandstones interbedded with coal and carbonaceous shale. Guo and others (2014) indicate that the tight sandstone layers and lenses contain a significant gas resource sourced mainly from the coals - a geologic framework that is very similar to that of major tight-gas fields in the western United States. In the southern Junggar Basin, natural gas has been discovered in coal and shale within the Badaowan (Petromin Resources, 2009); possible resource exploration concepts include tight gas, shale gas, and coalbed gas (Guo and others, 2014). This 2018 USGS assessment focused on tight-gas resources in sandstone that are analogous to tight-gas sandstones in the Upper Cretaceous Mesaverde Group in the Piceance Basin, Colorado (Johnson and Roberts, 2003; Cumella, 2009).

\section{Assessment Units}

The USGS defined two assessment units for this study. The Santanghu Permian Lucaogou Continuous Oil Assessment Unit (AU) is within the Permian Lucaogou Total Petroleum System of the Santanghu Basin (AltaySayan Folded Region Province), and the Lower Jurassic Badaowan Tight Gas AU is within the Jurassic Total Petroleum System in the Junggar Basin (Junggar Basin Province).

\section{Santanghu Permian Lucaogou Continuous Oil Assessment Unit}

The Permian Lucaogou Formation was deposited in northwest China within one of the world's largest known Phanerozoic lake basins, which was disrupted in the early Mesozoic Era by reverse faulting that produced mountainous uplifts and divided the formerly extensive lake system into several smaller basins (Carroll and Wartes, 2003). These basins, including the Santanghu and Junggar (fig. 1), have accumulated kilometers of Mesozoic and Cenozoic nonmarine sediment.

The Lucaogou Formation in the Santanghu basin is 0-350 meters (m) thick (Liu and others, 2017) and includes rich lacustrine source rock in the Tiaohu and Malang sags in the central part of the basin (Liang and others, 2014; Liu and others, 2018). The Santanghu Permian Lucaogou Continuous Oil AU (fig. 1) encompasses the area of these two sags. Oil has migrated vertically from the organic-rich mudstones and can be produced from interbedded tight sandstones, dolomitic mudstones, tuffaceous dolomites, and carbonates in the Lucaogou as well as from tuffs in the directly overlying Tiaohu Formation (Liang and others, 2014; Hackley and others, 2016). Reuters (2012) reported subeconomic quantities of oil in 15 of 35 PetroChina wells and commercial flow rates in 4 wells; Liang and others (2014) reported industrial oil flows from Tiaohu tuffaceous reservoirs in at least 5 wells.

The lacustrine mudstone of the Lucaogou records a transition from a shallow, anoxic, stratified saline environment to a deep freshwater lake based on petrographic and geochemical analyses (Liu and others, 2017). The mudstone is dolomitic, and an upsection decrease in dolomite is consistent with decreasing salinity (Hackley and others, 2016). The average total organic carbon is 6.4 weight percent with a maximum measured value of 18 weight percent (Liu and others, 2012), and organic matter is predominantly Type I (Hackley and others, 2016). Vitrinite reflectance $\left(\mathrm{R}_{0} ; 0.5-1.0\right.$ percent) and organic geochemical analyses indicate that the Lucaogou is within the initial part of the oil-generation window (Liu and others, 2017). Liu and others (2012) concluded that it began to generate oil at the end of the Cretaceous. The Lucaogou Formation is overpressured (pressure coefficients of 1.1-1.2), likely because of hydrocarbon generation and rapid burial (Liu and others, 2012).

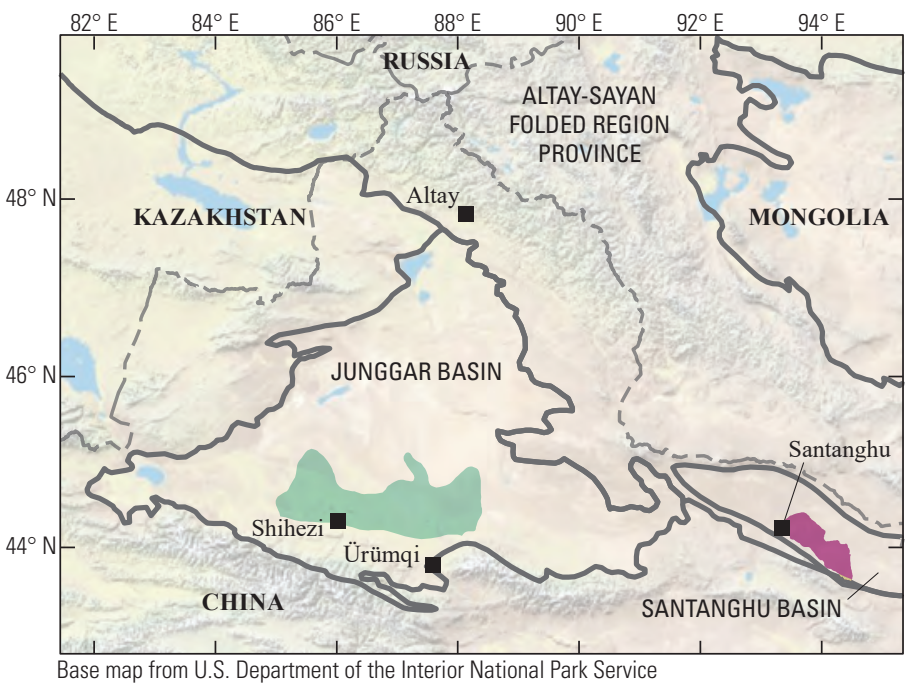

XPLANATION

Santanghu Permian Lucaogou Continuous Oil AU

Lower Jurassic Badaowan Tight Gas AU

Province boundary
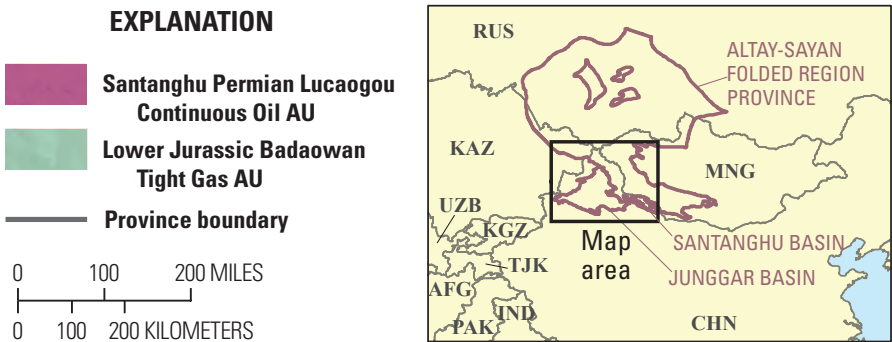

Figure 1. Map showing locations of the Santanghu Permian Lucaogou Continuous Oil Assessment Unit (AU) within the Santanghu Basin (Altay-Sayan Folded Region Province) and the Lower Jurassic Badaowan Tight Gas AU within the Junggar Basin (Junggar Basin Province). Approximate Santanghu Basin boundary (part) is also shown. 


\section{Lower Jurassic Badaowan Tight Gas Assessment Unit}

In the southern part of the Junggar Basin, interbedded fluvial sandstones, carbonaceous shales, and coal of the Lower Jurassic Badaowan Formation are at current depths of 4-7 kilometers, achieving thermal maturities of 0.5-2.2 percent $\mathrm{R}$ (Guo and others, 2014). The gross thickness of the formation ranges from 0 to $800 \mathrm{~m}$ (Yang and others, 2015). The average total organic carbon values of Badaowan coal beds and carbonaceous shales are 60 and 1.7 weight percent, respectively, and the kerogen is predominantly Type III (Guo and others, 2014). According to the petroleum-generation-potential modeling of Guo and others (2014), the Badaowan source rocks generated gas in the Late Cretaceous to Neogene with peak generation in the Paleogene and Neogene. Specific timing would have varied with location and depth in the strongly asymmetric, southward-thickening basin.

The Lower Jurassic Badaowan Tight Gas AU (fig. 1) includes the area where $\mathrm{R}_{0}$ is greater than 0.8 percent (Guo and others, 2014), corresponding to the approximate maturity threshold for thermogenic methane generation from coal (Tang and others, 1996). The assessment unit is bounded on the south by the northern edge of the fold and thrust belt that strongly deforms the southern margin of the basin. The Badaowan within this area is hundreds of meters thick (gross thickness; Yang and others, 2015), so thickness is not a limiting factor.

Table 1 lists the principal input data used for the Lucaogou and Badaowan assessments. Continuous oil and gas accumulations in the United States were used as analogs.

\section{Undiscovered Resources Summary}

The USGS quantitatively assessed continuous oil and gas resources in two assessment units in northwest China - one each in the Junggar and Santanghu Basins (table 2). In these two assessment units, the estimated mean total for continuous oil resources is 241 million barrels of oil (MMBO) with an F95-F5 range from 55 to $527 \mathrm{MMBO}$. The estimated mean total for continuous gas resources is 10,109 billion cubic feet (BCFG), or 10.1 trillion cubic feet of gas, with an F95-F5 range from 2,239 to 22,274 BCFG. The estimated mean total is 201 million barrels of natural gas liquids (MMBNGL) with an F95-F5 range from 42 to 465 MMBNGL. These resource estimates are for undiscovered, technically recoverable oil, gas, and natural gas liquids and do not reflect volumes of economically recoverable resources.

Table 1. Key input data for two continuous assessment units in northwestern China.

[AU, assessment unit; \%, percent; EUR, estimated ultimate recovery per well; MMBO, million barrels of oil; BCFG, billion cubic feet of gas. Well drainage area, success ratio, and EUR are defined partly using U.S. tight-oil and tight-gas analogs. The average EUR input is the minimum, median, maximum, and calculated mean. Shading indicates not applicable]

\begin{tabular}{|l|c|c|c|c|c|c|c|c|}
\hline \multirow{2}{*}{$\begin{array}{c}\text { Assessment input data- } \\
\text { Continuous AUs }\end{array}$} & \multicolumn{3}{c|}{ Santanghu Permian Lucaogou Continuous Oil AU } & \multicolumn{4}{c|}{ Lower Jurassic Badaowan Tight Gas AU } \\
\cline { 2 - 9 } & Minimum & Mode & Maximum & Calculated mean & Minimum & Mode & Maximum & Calculated mean \\
\hline Potential production area of AU (acres) & 1,000 & 400,000 & 854,000 & 418,333 & 1,000 & $2,000,000$ & $4,486,450$ & $2,162,483$ \\
\hline Average drainage area of wells (acres) & 40 & 80 & 120 & 80 & 40 & 80 & 120 \\
\hline Success ratio (\%) & 10 & 50 & 90 & 50 & 10 & 50 & 90 \\
\hline Average EUR (MMBO, oil; BCFG, gas) & 0.04 & 0.085 & 0.2 & 0.091 & 0.2 & 0.7 & 1.5 \\
\hline AU probability & 1.0 & & & & 1.0 & & 0.734 \\
\hline
\end{tabular}

Table 2. Results for two continuous assessment units in northwestern China.

[MMBO, million barrels of oil; BCFG, billion cubic feet of gas; NGL, natural gas liquids; MMBNGL, million barrels of natural gas liquids. Results shown are fully risked estimates. F95 represents a 95-percent chance of at least the amount tabulated; other fractiles are defined similarly. Fractiles are additive under the assumption of perfect positive correlation. Shading indicates not applicable]

\begin{tabular}{|c|c|c|c|c|c|c|c|c|c|c|c|c|c|c|}
\hline \multirow{3}{*}{$\begin{array}{l}\text { Total petroleum systems } \\
\text { and assessment units (AUs) }\end{array}$} & \multirow{3}{*}{$\begin{array}{c}\text { AU } \\
\text { probability }\end{array}$} & \multirow{3}{*}{$\begin{array}{l}\text { Accumulation } \\
\text { type }\end{array}$} & \multicolumn{12}{|c|}{ Total undiscovered resources } \\
\hline & & & \multicolumn{4}{|c|}{ Oil (MMBO) } & \multicolumn{4}{|c|}{ Gas (BCFG) } & \multicolumn{4}{|c|}{ NGL (MMBNGL) } \\
\hline & & & F95 & F50 & F5 & Mean & F95 & F50 & F5 & Mean & F95 & F50 & F5 & Mean \\
\hline \multicolumn{15}{|c|}{ Permian Lucaogou Total Petroleum System (Santanghu Basin) } \\
\hline $\begin{array}{l}\text { Santanghu Permian Lucaogou } \\
\text { Continuous Oil AU }\end{array}$ & 1.0 & Oil & 55 & 213 & 527 & 241 & 14 & 61 & 170 & 72 & 0 & 0 & 1 & 0 \\
\hline \multicolumn{15}{|c|}{ Jurassic Total Petroleum System (Junggar Basin) } \\
\hline $\begin{array}{l}\text { Lower Jurassic Badaowan Tight } \\
\text { Gas AU }\end{array}$ & 1.0 & Gas & & & & & 2,225 & 8,784 & 22,104 & 10,037 & 42 & 171 & 464 & 201 \\
\hline $\begin{array}{l}\text { Total undiscovered continuous } \\
\text { resources }\end{array}$ & & & 55 & 213 & 527 & 241 & 2,239 & 8,845 & 22,274 & 10,109 & 42 & 171 & 465 & 201 \\
\hline
\end{tabular}

\section{References Cited}

Carroll, A.R., and Wartes, M.A., 2003, Organic carbon burial by large Permian lakes, northwest China, in Chan, M.A., and Archer, A.W., eds., Extreme depositional environments-Mega end members in geologic time: Boulder, Colo., Geological Society of America, Special Pape 370, p. 91-104

Cumella, S., 2009, Geology of the Piceance Basin Mesaverde gas accumulation: American Association of Petroleum Geologists, Search and Discovery Article No. 110106, 22 p., accessed November 1, 2018, at http://www.searchanddiscovery.com/documents/2009/110106cumella/ ndx_cumella.pdf.

Guo Jigang, Pang Xiongqi, Guo Fengtao, Wang Xulong, Xiang Caifu, Jiang Fujie, Wang Pengwei, Xu Jing, Hu Tao, and Peng Weilong, 2014, Petroleum generation and expulsion characteristics of Lower and Middle Jurassic source rocks on the southern margin of Junggar Basin, northwest China-Implications for unconventional gas potential: Canadian Journal of Earth Sciences, v. 51, no. 6, p. 537-557. [Also available at https://doi.org/10.1139/cjes-2013-0200.]

Hackley, P.C.; Fishman, N.; Wu Tao; and Baugher, G., 2016, Organic petrology and geochemistry of mudrocks from the lacustrine Lucaogou Formation, Santanghu Basin, northwest ChinaApplication to lake basin evolution: International Journal of Coal Geology, v. 168, part 1, p. 20-34. [Also available at https://doi.org/10.1016/j.coal.2016.05.011.]

Johnson, R.C., and Roberts, S.B., 2003, The Mesaverde Total Petroleum System, Uinta-Piceance Province, Utah and Colorado, chap. 7 of USGS Uinta-Piceance Assessment Team, Petroleum systems and geologic assessment of oil and gas in the Uinta-Piceance Province, Utah and Colorado: U.S. Geological Survey Digital Data Series DDS-69-B, 68 p.

Liang Hao, Li Xinning, Ma Qiang, Liang Hui, Luo Quansheng, Chen Xuan, Bai Guojuan, Zhang Qi, and Meng Yuanlin, 2014, Geological features and exploration potential of Permian Tiaoh Formation tight oil, Santanghu Basin, NW China: Petroleum Exploration and Development, v. 41 , no. 5 , p. $616-627$

Liu Bo; Bechtel, A.; Gross, D.; Fu Xiaofei; Li Xinning; and Sachsenhofer, R.F., 2018, Middle Permian environmental changes and shale oil potential evidenced by high-resolution organic petrology, geochemistry and mineral composition of the sediments in the Santanghu Basin, northwest China: International Journal of Coal Geology, v. 85, p. 119-137. [Also available at https://doi.org/10.1016/j.coal.2017.11.015.]

Liu Bo; Bechtel, A.; Sachsenhofer, R.F.; Gross, D.; Gratzer, R.; and Chen Xuan, 2017, Depositional environment of oil shale within the second member of Permian Lucaogou Formation in the Santanghu Basin, northwest China: International Journal of Coal Geology, v. 175, p. 10-25. [Also available at https://doi.org/10.1016/j.coal.2017.03.011.]
Liu Bo, Lü Yanfang, Zhao Rong, Tu Xiaoxian, Guo Xiaobo, and Shen Ying, 2012, Formation overpressure and shale oil enrichment in the shale system of Lucaogou Formation, Malang Sag, Santanghu Basin, NW China: Petroleum Exploration and Development, v. 39, no. 6, p. $744-750$

Petromin Resources, 2009, Project update and confirmation of extensive thickness of prospective shale gas zone: Petromin Resources, accessed November 18, 2015, at http:/www.prnewswire.com/ news-releases/project-update-confirmation-of-extensive-thickness-of-prospective-shale-gaszone-62156782.html.

Potter, C.J., Schenk, C.J., Tennyson, M.E., Klett, T.R., Gaswirth, S.B., Leathers-Miller, H.M., Finn, T.M., Brownfield, M.E., Pitman, J.K., Mercier, T.J., Le, P.A., and Drake, R.M., II, 2017, Assessment of Permian tight oil and gas resources in the Junggar basin of China, 2016: U.S. Geological Survey Fact Sheet 2017-3021, 2 p. [Also available at https://doi.org/10.3133/fs20173021.]

Reuters, 2012, PetroChina in talks with Shell, Hess to explore shale oil: Beijing, Reuters, accessed November 6, 2018, at http://reuters.fr/article/idUKL3E8F50OO20120405.

Tang, Y., Jenden, P.D., Nigrini, A., and Teerman, S.C., 1996, Modeling early methane generation in coal: Energy and Fuels, v. 10, no. 3, p. 659-671.

Yang Wan; Feng Qiao; Liu Yiqun; Tabor, N.; Miggins, D.; Crowley, J.L.; Lin Jinyan; and Thomas, S., 2010, Depositional environments and cyclo- and chrono-stratigraphy of uppermost Carboniferous-Lower Triassic fluvial-lacustrine deposits, southern Bogda Mountains, NW China-A terrestrial paleoclimatic record of mid-latitude NE Pangea: Global and Planetary Change, v. 73, nos. 1-2, p. 15-113.

Yang Yong-Tai, Song Chuan-Chun, and He Sheng, 2015, Jurassic tectonostratigraphic evolution of the Junggar basin, NW China-A record of Mesozoic intraplate deformation in Central Asia: Tectonics, v. 34, no. 1, p. 86-115. [Also available at https://doi.org/ 10.1002/2014TC003640.

\section{Northwest China Assessment Team}

Christopher J. Potter, Christopher J. Schenk, Tracey J. Mercier, Marilyn E. Tennyson,

Thomas M. Finn, Cheryl A. Woodall, Heidi M. Leathers-Miller, Kristen R. Marra, Phuong A. Le, Ronald M. Drake II, Michael E. Brownfield, and Janet K. Pitman

\section{For More Information}

Assessment results are also available at the USGS Energy Resources Program website at https://energy.usgs.gov. 